Article

\title{
Verification of a Nondestructive Method for Assessing the Humidity of Saline Brick Walls in Historical Buildings
}

\author{
Anna Hoła ${ }^{D}$ and Łukasz Sadowski *D \\ Department of Building Engineering, Wroclaw University of Science and Technology, \\ Wybrzeże Wyspiańskiego 27, 50-370 Wroclaw, Poland; anna.hola@pwr.edu.pl \\ * Correspondence: lukasz.sadowski@pwr.edu.pl
}

Received: 28 August 2020; Accepted: 29 September 2020; Published: 2 October 2020

check for updates

\begin{abstract}
The paper presents the results of the verification of the neural method for assessing the humidity of saline brick walls. The method was previously developed by the authors and can be useful for the nondestructive assessment of the humidity of walls in historic buildings when destructive intervention during testing is not possible due to conservation restrictions. However, before being implemented in construction practice, this method requires validation by verification on other historic buildings, which to date has not been done. The paper presents the results of such verification, which has never been carried out before, and thus extends the scope of knowledge related to the issue. For experimental verification of the artificial neural network (ANN), the results of moisture tests of two selected historic buildings, other than those used for ANN learning and testing processes, were used. An artificial unidirectional multilayer neural network with backward error propagation and the algorithm for learning conjugate gradient (CG) was found to be useful for this purpose. The obtained satisfactory value of the linear correlation coefficient $R$ of 0.807 and low average absolute error $|\Delta \mathrm{f}|$ of $1.16 \%$ confirms this statement. The values of average relative error $|R E|$ of $19.02 \%$, which were obtained in this research, were not very high for an in-situ study. Moreover, the relative error values $|R E|$ were mostly in the range of $15 \%$ to $25 \%$.
\end{abstract}

Keywords: historic buildings; brick walls; nondestructive testing; artificial neural networks

\section{Introduction}

The problem of excessive moisture in brick walls usually concerns old buildings that have been used for several dozen years or more [1-6]. A special group of such old buildings concerns those that are included in the register of monuments and those that are subjected to special conservation protection. The building owners' duties include their proper maintenance and preservation; however, all works interfering with the historic tissue require prior permission from conservation authorities [7].

In the objects in question, the reason for excessive moisture is most often the lack of moisture insulation, the effect of which is the direct contact of the wall with the ground. Due to this, the water molecules contained in the ground-along with the salts dissolved in them-gradually penetrate into the wall's components, in turn moisturizing and salting it. The level of dampness and salinity of walls in such buildings usually significantly exceeds the permissible levels determined on the basis of classifications commonly accepted in technical literature [2-6], which are presented in Figure 1. 


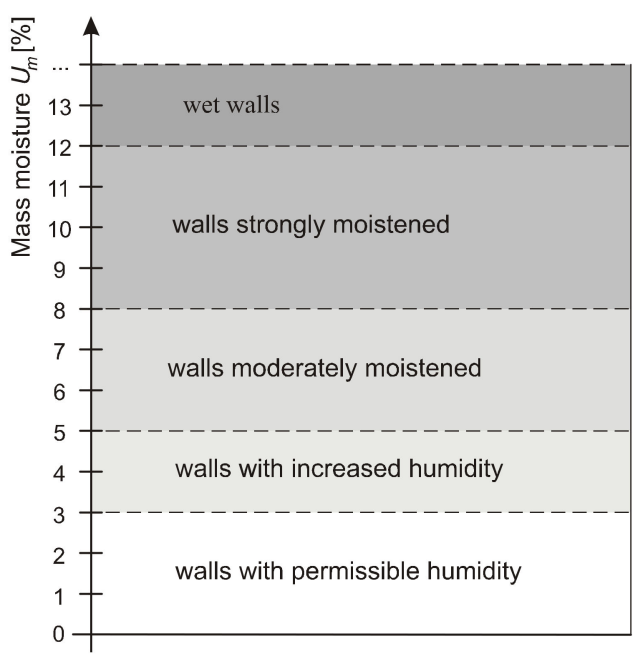

(a)

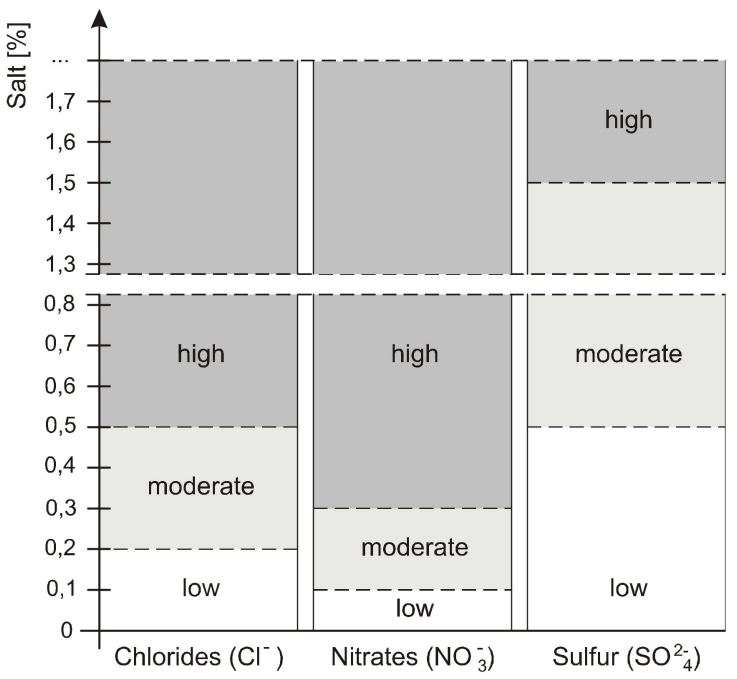

(b)

Figure 1. Classification of the moisture (a) and salinity (b) of brick walls (based on [8-14]).

The effect of long-term excessive moisture and salinity in a wall is its susceptibility to frost destruction over time and the falling off of plaster. This is followed by the chipping of brick and mortar fragments, which gradually reduces the wall's cross-section and decreases its strength.

In order to stop the above-mentioned destructive processes, it is first of all necessary to perform tests aimed at determining the amount and causes of the moisture. Of all the known methods for testing the humidity of brick walls, the most reliable results are obtained when using the destructive direct gravimetric method [11]. It allows the moisture value to be determined on the surface of the tested partition, as well as in its thickness. When using it, however, it is necessary to collect in-situ samples of material for laboratory tests. In the case of historic buildings, masonry sampling for moisture testing is only possible to a very limited extent. Paper [12] highlights the fact that destructive methods are not suitable for historical buildings of great architectural significance and also that nondestructive testing methods play an important role in the diagnostics of these buildings.

Of the nondestructive methods, electrical methods such as the dielectric, resistance, and microwave methods are considered to be very useful and are commonly used for testing brick wall moisture [15-18]. When conducting tests using these methods, it is not the humidity that is directly measured but instead a different physical feature of the wall. The value of this feature is affected by the water that is contained in the wall. Therefore, in the dielectric method the phenomenon of changing the dielectric constant of the tested material due to moisture is used; in the resistance method the change in material resistance depends on the amount of water it contains; while in the microwave method the attenuation of microwaves passing through moist material is measured.

The measurement result when using these methods is the unnamed parameter $X$. Therefore, in order to determine the moisture value, it is necessary to scale the apparatus on the tested object and determine the correlation relationship $U_{m}-X$, in which $U_{m}$ usually means mass humidity. For this purpose, a specified number of moist masonry samples should be taken, and their mass humidity should be determined using the gravimetric method. The obtained humidity values should then be correlated with the corresponding readings of the meter that was used for the testing. A lack of consent of conservator services for taking samples often results in the skipping of the scaling procedure, and instead the results of scaling that were conducted by the apparatus manufacturer are being used. It is usually made on the basis of testing moist masonry samples that contain water without soluble salts, whereas in moist brick masonry, walls of existing objects such salts are present. As was shown in [19], 
their content significantly affects the results of tests that were obtained using electrical methods and also causes the overstatement of the estimated humidity value when compared to the actual value. In order to eliminate troublesome scaling of the apparatus on the examined object, it was proposed to use the possibilities offered by artificial intelligence. Nowadays, artificial intelligence is extensively used when predicting humidity values in various parts of buildings made of brick. The authors of works [20-22] recently determined the compressive strength of brick-mortar masonry based on neural networks, neuro-fuzzy inference systems, and nondestructive tests. The authors of work [23] employed support vector machines, neural networks, and Gaussian Naïve Bayes techniques for the evaluation of damage in a turn-of-the-century, six-story building with timber frames and masonry walls. The authors of work [24] used mobile deep learning for damage detection of historic masonry buildings. Another attempt to classify the damage of masonry historic structures based on convolutional neural networks and still images was presented in [25]. Convolutional neural networks were also used in [26,27] for the prediction and metamodeling of the hygrothermal behavior and performance of building components. In [28], a method based on numerical experiments for the identification of the thermal resistance of exterior walls of buildings was presented. However, there is still a lack of research that aims to use artificial neural networks and nondestructive methods to assess the humidity of saline brick walls in historic buildings.

This is why the authors of this publication, based on experimental research and numerical analysis, have developed a nondestructive neural method of assessing the humidity of saline brick walls in historic buildings, which is described in detail in [29]. This method is based on the use of artificial neural networks that are learned and tested on a data set built for this purpose. However, this method requires validation by verification on other historic buildings. This has not been done before and can be seen to be necessary before implementing it in construction practice. This issue is currently the subject of research, and the purpose of this work is to present the first results of such verification carried out on two historic buildings selected for this purpose. As mentioned before, such verification has not been done to date and is therefore a new contribution to the knowledge related to the issue.

\section{Description of the Previously Developed Nondestructive Method for Assessing the Humidity of Saline Brick Walls in Historical Buildings}

As described in [29], data collection was obtained on the basis of research of in-situ brick walls of several selected historic buildings from various historical periods from the 14th to 19th centuries. The tests were carried out in several hundred places. The data set, which is fully available in [29], therefore included several hundred sets of test results, each of which consists of six parameters. Two basic dimensionless parameters, $X_{\mathrm{D}}$ and $X_{\mathrm{M}}$, describing the moisture of the wall, were determined using nondestructive, dielectric (Gann Hydromette Uni 2 meter with an active ball probe) and microwave (Trotec T 600 meter) methods. The use of the resistance method for testing was abandoned because its use in historic buildings is practically impossible due to the need to drill small holes in a wall for the proper application of the measuring head, which conservation services often do not agree to. The three auxiliary parameters $A, C$, and $S$, describing the molar concentration of nitrate, chloride, and sulphate salts harmful to the wall, were determined using the semi-quantitative method. However, the sixth parameter, $\mathrm{U}_{m}$, describing the actual mass moisture of the wall, and which is needed to teach artificial neural networks, was determined using the gravimetric method with the use of a laboratory dryer. As a result of numerical analysis, the type and structure of neural networks were selected, as shown in Figure 2. 
INPUT LAYER

Experimentally determined parameters
HIDDEN LAYER $\mathrm{K}=3$
OUTPUT LAYER

Identification parameter

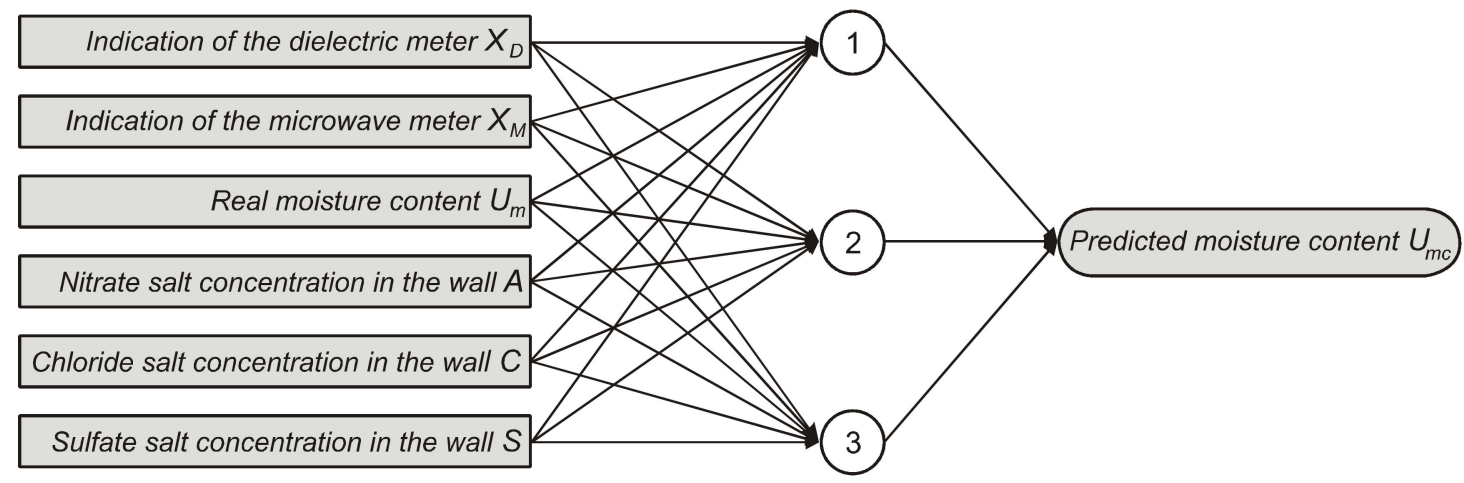

Figure 2. Structure of the artificial neural network used in [29].

Figure 3 shows the relationship between the real mass humidity $U_{m}$ obtained by the gravimetric method and the $U_{m c}$ humidity that was identified using an artificial neural network with the structure shown in Figure 2. Figure 3a shows this relationship in the learning process, while Figure $3 b$ shows this relationship in the testing process. Figure 3 a shows that the network correctly maps learning data and accurately identifies test data. This is demonstrated by the location of the points along the regression line, which corresponds to the ideal mapping, as well as the high values of the linear correlation coefficient $\mathrm{R}$, which are 0.919 and 0.928 , respectively, for the learning and testing process.

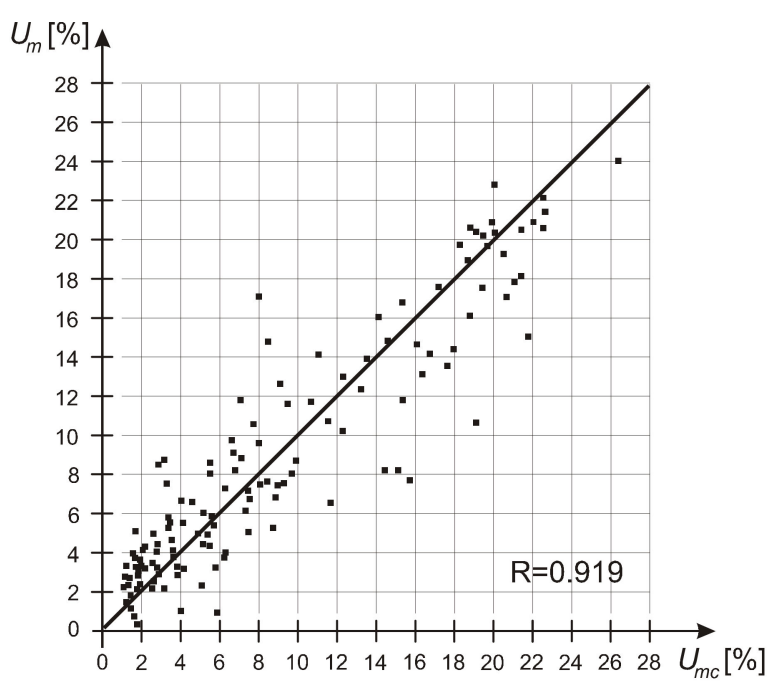

(a)

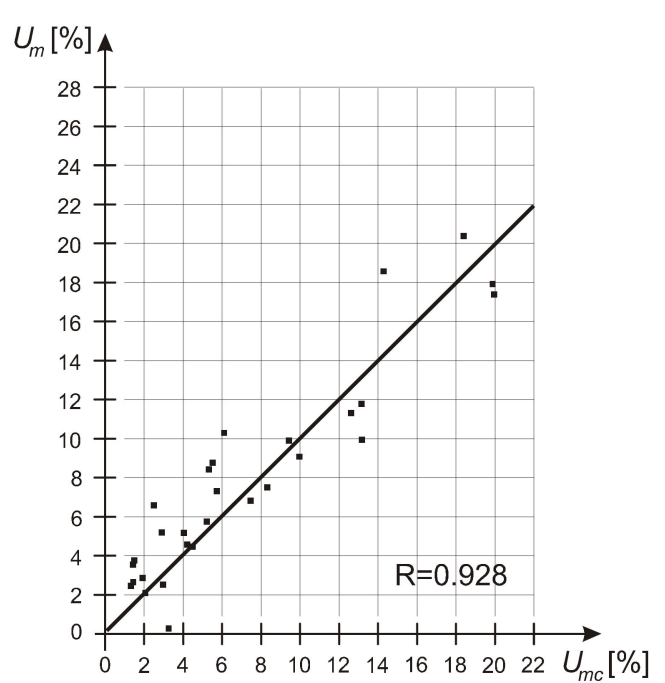

(b)

Figure 3. The relationship between the mass humidity, obtained using the gravimetric method, and humidity, which was identified by the network for the process of: (a) learning and (b) testing (based on the results presented in [29]).

The obtained satisfactory learning and testing results of the above-mentioned network indicate the possibility of a wider use of the developed method of the noninvasive assessment of the humidity of saline brick walls. This method seems to be very useful, especially in the case of historical buildings, where destructive interference during humidity and salinity tests should be kept to a minimum due to conservation restrictions [30-33]. 


\section{Test Results Used to Verify the ANN Model}

In order to carry out the experimental verification of the aforementioned artificial neural network, in-situ brick wall moisture tests were carried out on two historic buildings erected at the end of the 19th century, for which full ceramic brick and lime mortar were used. The research was carried out in autumn during cloudy days with no wind, sun, or rain. The outside air humidity was around $75 \%$ and the temperature was about $16^{\circ} \mathrm{C}$. The indoor relative humidity was $85 \% \pm 5 \%$ and the air temperature was $18^{\circ} \mathrm{C} \pm 3^{\circ} \mathrm{C}$.

Figures 4 and 5 present photos from the examined objects. In turn, the characteristics of the objects are given in Table 1. In the case of both buildings, traces of moisture are clearly visible on their walls, and the height of the capillary water fringe reaches over $100 \mathrm{~cm}$ above the ground level.
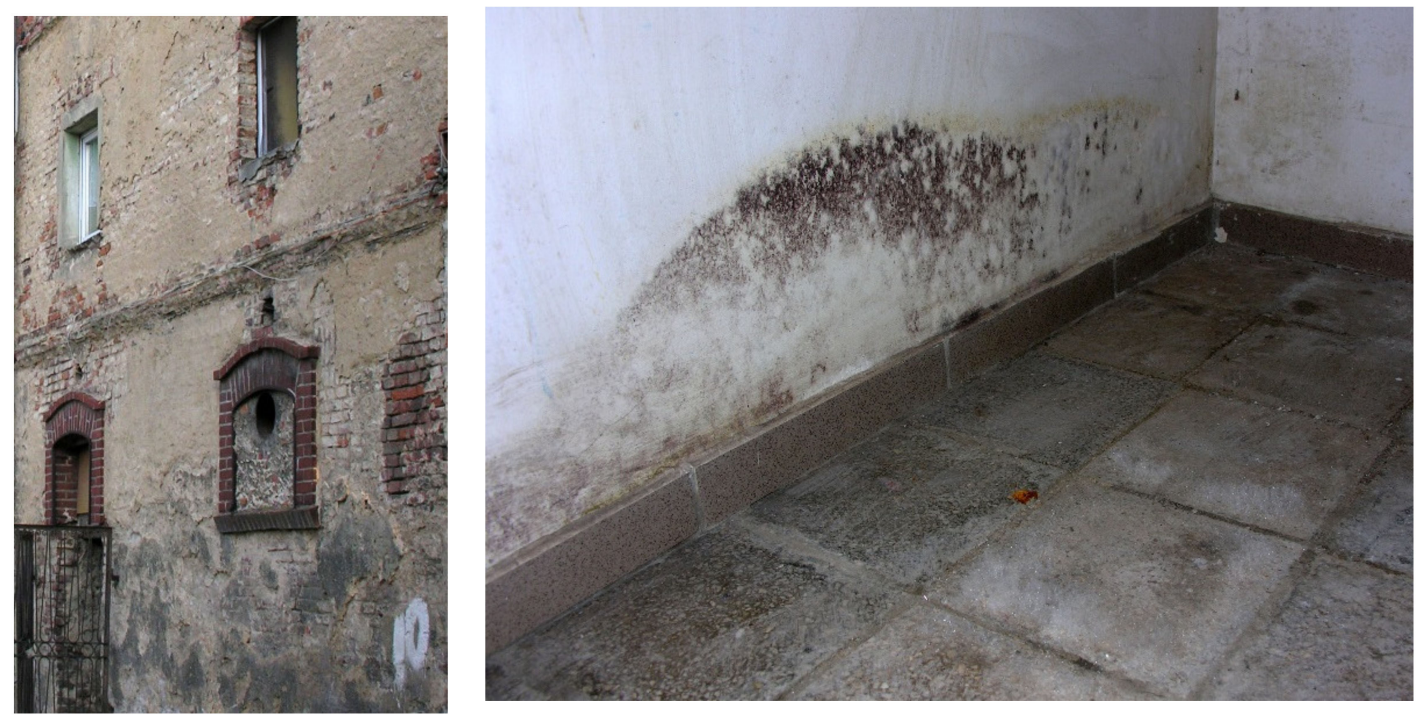

Figure 4. Photographs of selected fragments of a former farm building in Katy Wroclawskie.
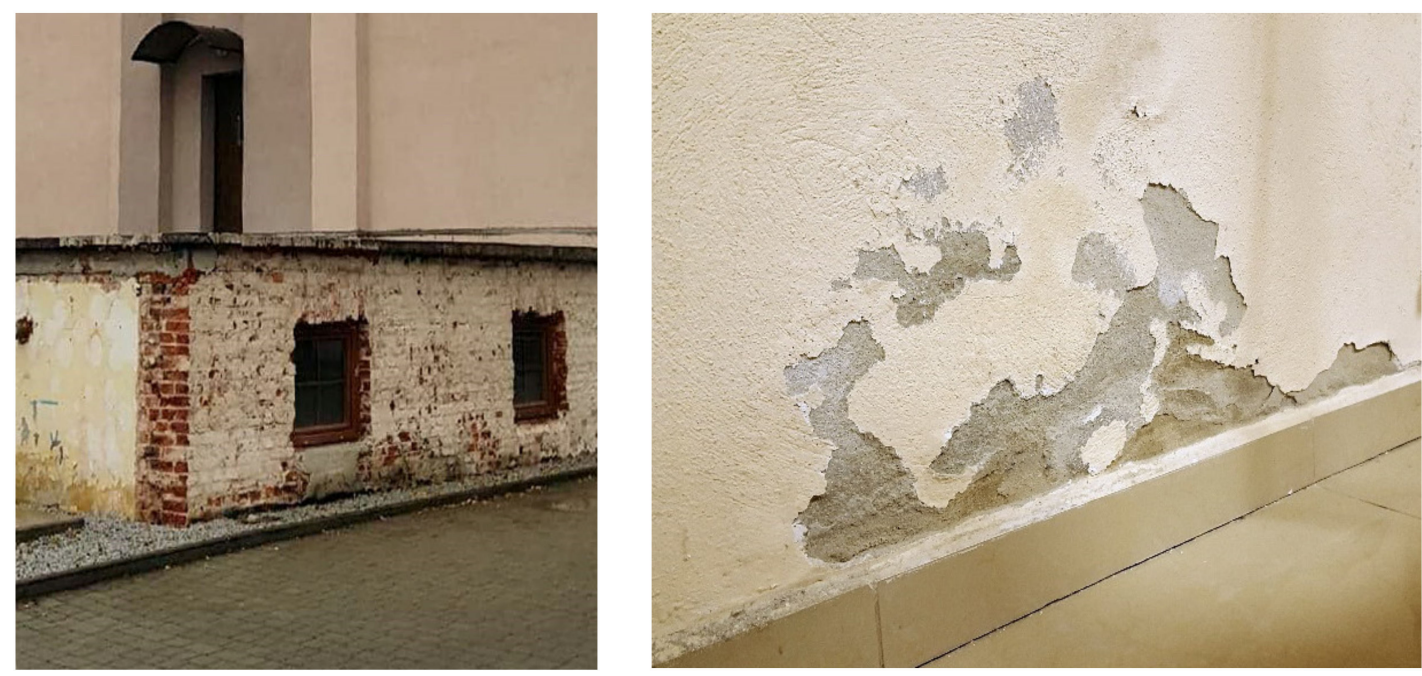

Figure 5. Pictures of selected fragments of the Redemptorist monastery in Wroclaw. 
Table 1. Characteristics of the facilities where the tests were conducted for the purpose of verifying the artificial neural network.

\begin{tabular}{|c|c|}
\hline \multicolumn{2}{|r|}{ Description of the Object } \\
\hline \multicolumn{2}{|r|}{ OBJECT NO. 1} \\
\hline Name, location & $\begin{array}{l}\text { post-farm building, } \\
\text { Katy Wroclawskie, Poland }\end{array}$ \\
\hline Date of construction & end of the nineteenth century \\
\hline Description of the object & $\begin{array}{l}\text { - erected on a rectangular plan with dimensions of } 55.0 \mathrm{~m} \times 10.0 \mathrm{~m} \\
\text { - the building has no basement, has two floors above ground, and a barren } \\
\text { attic covered by a steep gable roof } \\
\text { - served as an economic function for farm buildings; currently has a } \\
\text { residential and service function }\end{array}$ \\
\hline Place of measurement & $\begin{array}{l}\text { - brick basement walls } \\
\text { - wall thickness in the range of } 51 \mathrm{~cm} \text { to } 64 \mathrm{~cm}\end{array}$ \\
\hline \multicolumn{2}{|r|}{$\begin{array}{r}\text { OBJECT NO. } 2 \\
\end{array}$} \\
\hline Name, location & $\begin{array}{l}\text { Redemptorist monastery, } \\
\text { Wroclaw, Poland }\end{array}$ \\
\hline Date of construction & end of the nineteenth century \\
\hline Description of the object & $\begin{array}{l}\text { - erected on a rectangular plan with dimensions of } 27.0 \mathrm{~m} \times \sim 17.0 \mathrm{~m} \\
\text { basement, two floors above ground, and a usable attic covered with a steep } \\
\text { gable roof }\end{array}$ \\
\hline Place of measurement & $\begin{array}{l}\text { - brick walls of the basement-external and internal } \\
\text { - wall thickness in the range of } 55 \mathrm{~cm} \text { to } 75 \mathrm{~cm}\end{array}$ \\
\hline
\end{tabular}

Table 2 contains a set of data consisting of 15 sets of results, which were obtained on the basis of the tests of the historic buildings described above. Sets 1 to 7 were obtained from the post-farm building in Katy Wroclawskie and sets 8 to 15 from the monastery building in Wroclaw. As with previous studies [29], each set of results included two dimensionless parameters $X_{D}$ and $X_{M}$, determined nondestructively using the dielectric (with the use of the Gann Hydromette Uni 2 meter with an active ball probe) and microwave (with the use of the Trotec $\mathrm{T} 600$ meter) methods, respectively; three parameters $A, C$, and $S$, describing the molar concentrations of nitrate, chloride, and sulfate salts in walls, determined using the semi-quantitative method; as well as the $U_{m}$ parameter obtained using the gravimetric method (with the use of a laboratory dryer), describing the actual mass humidity of the wall (in\%). The samples were dried at a temperature of $+105^{\circ} \mathrm{C} \pm 1^{\circ} \mathrm{C}$. 
Table 2. Test results of sets prepared for experimental verification of the artificial neural network.

\begin{tabular}{cccccccc}
\hline $\begin{array}{c}\text { Data set } \\
\text { no. } \\
{[-]}\end{array}$ & $\begin{array}{c}\text { Height of the } \\
\text { Measuring } \\
\text { Point above } \\
\text { Ground/Floor } \\
\text { Level [cm] }\end{array}$ & $\begin{array}{c}\text { Indication } \\
\text { of the } \\
\text { Dielectric } \\
\text { Meter } \\
\boldsymbol{X}_{\mathbf{D}}[-]\end{array}$ & $\begin{array}{c}\text { Indication } \\
\text { of the } \\
\text { Microwave } \\
\text { Meter } \\
\boldsymbol{X}_{\mathbf{M}}[-]\end{array}$ & $\begin{array}{c}\text { Salt } \\
\text { Concentration } \\
\text { in the Wall } \\
A[\%]\end{array}$ & $\begin{array}{c}\text { Salt } \\
\text { Concentration } \\
\text { in the Wall } \\
C[\%]\end{array}$ & $\begin{array}{c}\text { Salt } \\
\text { Concentration } \\
\text { in the Wall } \\
S[\%]\end{array}$ & $\begin{array}{c}\text { Real Mass } \\
\text { Humidity of } \\
\text { the Wall }\end{array}$ \\
\hline 1 & 100 & 135.00 & 58.40 & 0.04 & 0.20 & 0.10 & 8.32 \\
\hline 2 & 50 & 137.10 & 68.30 & 0.45 & 0.50 & 0.01 & 9.75 \\
\hline 3 & 15 & 130.00 & 72.50 & 0.50 & 0.20 & 0.30 & 6.87 \\
\hline 4 & 100 & 89.70 & 47.20 & 0.35 & 1.20 & 0.25 & 4.57 \\
\hline 5 & 100 & 89.30 & 35.80 & 0.02 & 0.20 & 0.00 & 5.50 \\
\hline 6 & 15 & 39.80 & 30.60 & 0.03 & 0.40 & 0.00 & 3.00 \\
\hline 7 & 10 & 133.60 & 73.40 & 0.50 & 0.45 & 0.50 & 7.21 \\
\hline 8 & 10 & 134.00 & 23.10 & 0.29 & 0.35 & 0.50 & 6.18 \\
\hline 9 & 50 & 104.00 & 35.70 & 0.22 & 0.45 & 0.05 & 4.00 \\
\hline 10 & 100 & 78.00 & 39.60 & 0.42 & 0.30 & 0.00 & 4.95 \\
\hline 11 & 50 & 87.60 & 31.00 & 0.03 & 0.30 & 0.01 & 4.17 \\
\hline 12 & 100 & 129.90 & 49.60 & 0.03 & 0.20 & 0.03 & 7.14 \\
\hline 13 & 100 & 34.60 & 24.10 & 0.10 & 0.25 & 0.03 & 2.01 \\
\hline 14 & 50 & 100.24 & 39.50 & 0.23 & 0.33 & 0.16 & 5.09 \\
\hline 15 & 10 & 111.06 & 51.16 & 0.27 & 0.44 & 0.21 & 6.43 \\
\hline
\end{tabular}

Table 3 summarizes selected statistical characteristics of the obtained test results.

Table 3. List of selected statistical characteristics of parameters.

\begin{tabular}{ccccccc}
\hline \multirow{2}{*}{ Name and Symbol of the Characteristic } & \multicolumn{7}{c}{ Parameter Symbol } \\
\cline { 2 - 7 } & $\boldsymbol{X}_{\mathbf{D}}[-]$ & $\boldsymbol{X}_{\mathbf{M}}[-]$ & $A[\%]$ & $C[\%]$ & $S[\%]$ & $U_{m}[\%]$ \\
\hline Average value $\overline{x_{i}}$ & 34.60 & 23.10 & 0.02 & 0.20 & 0.00 & 2.01 \\
\hline Maximum value $x_{\max }$ & 137.10 & 73.40 & 0.50 & 1.20 & 0.50 & 9.75 \\
\hline Minimum value $x_{\min }$ & 102.26 & 45.33 & 0.23 & 0.38 & 0.14 & 5.68 \\
\hline Standard deviation $S_{\mathrm{x}}$ & 32.15 & 16.12 & 0.18 & 0.24 & 0.17 & 1.97 \\
\hline
\end{tabular}

\section{Verification of the Artificial Neural Network}

The results of the experimental verification of an unidirectional multilayer neural network (with back error propagation, the conjugate gradient algorithm (CG), and the number of hidden layer neurons equal to 3), which was previously taught and tested based on the results of the research presented in [29], are presented below. A total of 15 result sets were accepted for verification. This network generated a mass humidity value $U_{m c}$ at each point. These values were compared with the actual $U_{m}$ values obtained experimentally using the gravimetric method.

Figure 6 shows the relationship between $U_{m}$ humidity obtained on the basis of gravimetric tests and $U_{m c}$ humidity identified by the network for the experimental verification process. The obtained results show that the artificial neural network correctly mapped the verification data. This is evidenced by the location of points along the regression line, which correspond to the ideal mapping, and also the satisfactory value of the linear correlation coefficient $R$ equal to 0.807 . 


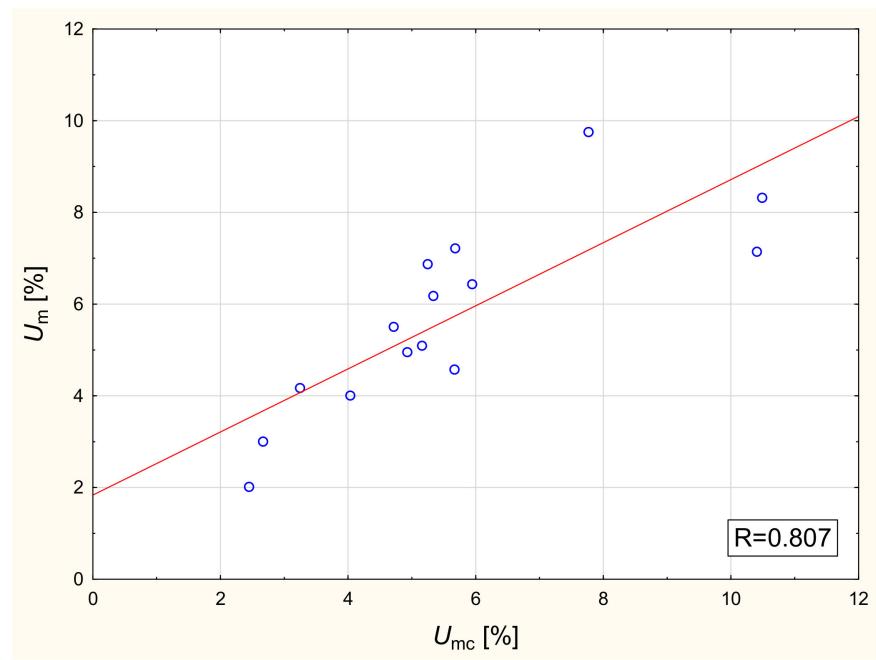

Figure 6. Relationship between $U_{m}$ mass humidity obtained on the basis of gravimetric tests and $U_{m c}$ humidity identified by the neural network for experimental verification.

Table 4 presents a comparative comparison of the $U_{m}$ and $U_{m c}$ humidity values determined using the gravimetric method and by means of the artificial neural network, respectively.

The results of the experimental verification presented in Table 3 indicate the correct identification of validation data. This is evidenced by the low average absolute error $|\Delta \mathrm{f}|$ value of $1.16 \%$ and the average relative error $|R E|$ of $19.02 \%$ (not very high for an in-situ study). It is also worth noting that the average $U_{m c}$ humidity value of $5.59 \%$ identified by the ANN is close to the $U_{m}$ humidity value of $5.68 \%$ obtained by means of a test using the gravimetric method. According to the authors, the obtained results can be considered satisfactory.

Table 4. Comparative list of selected $U_{m}$ and $U_{m c}$ humidity values determined using the gravimetric method and artificial neural network, respectively.

\begin{tabular}{|c|c|c|c|c|}
\hline Designation of Measuring Points & $\begin{array}{c}\text { Moisture Content } \\
\text { Obtained during Tests } \\
\text { Using the Gravimetric } \\
\text { Method }\end{array}$ & $\begin{array}{l}\text { Moisture Content } \\
\text { Identified by the } \\
\text { ANN }\end{array}$ & $\begin{array}{l}\text { Absolute } \\
\text { Error }\end{array}$ & $\begin{array}{c}\text { Relative } \\
\text { Error }\end{array}$ \\
\hline & $U_{m}$ & $U_{m c}$ & $|\Delta \mathbf{f}|$ & |RE \\
\hline & $\%$ & $\%$ & $\%$ & $\%$ \\
\hline 1 & 8.32 & 10.49 & 2.17 & 20.71 \\
\hline 2 & 9.75 & 7.77 & 1.98 & 25.46 \\
\hline 3 & 6.87 & 5.25 & 1.62 & 30.82 \\
\hline 4 & 4.57 & 5.67 & 1.10 & 19.40 \\
\hline 5 & 5.50 & 4.72 & 0.78 & 16.42 \\
\hline 6 & 3.00 & 2.67 & 0.33 & 12.53 \\
\hline 7 & 7.21 & 5.68 & 1.53 & 26.93 \\
\hline 8 & 6.18 & 5.34 & 0.84 & 15.80 \\
\hline 9 & 4.00 & 4.04 & 0.04 & 0.87 \\
\hline 10 & 4.95 & 4.93 & 0.02 & 0.31 \\
\hline 11 & 4.17 & 3.25 & 0.92 & 28.25 \\
\hline 12 & 7.14 & 10.41 & 3.27 & 31.43 \\
\hline 13 & 2.01 & 2.45 & 0.44 & 18.03 \\
\hline 14 & 5.09 & 5.16 & 1.01 & 17.38 \\
\hline 15 & 6.43 & 5.95 & 1.29 & 21.01 \\
\hline Mean value & 5.68 & 5.59 & 1.16 & 19.02 \\
\hline
\end{tabular}


Figure 7 presents the relative error histogram $|R E|$ of $U_{m}$ mass humidity obtained using the gravimetric method, as well as the $U_{m c}$ humidity identified by means of an artificial neural network for experimental verification. The figure also shows that the relative error values $|R E|$ are mostly in the range of $15 \%$ to $25 \%$, which indicates a satisfactory distribution of the obtained results.

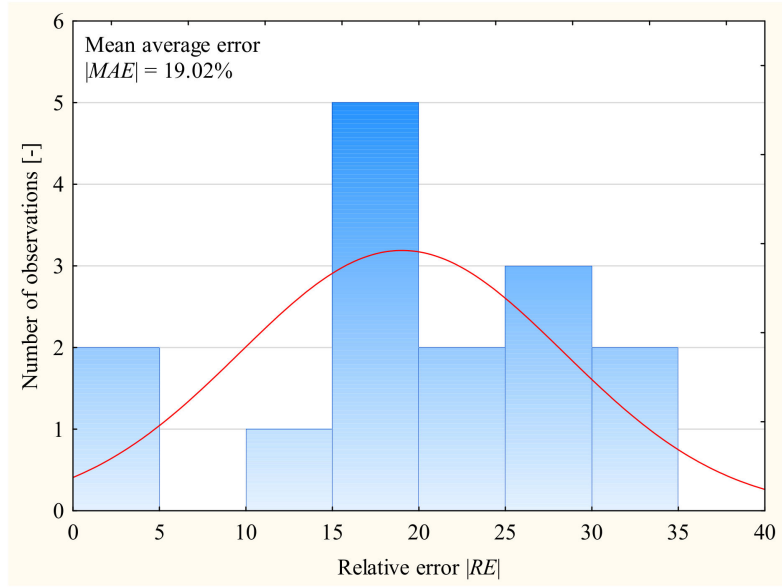

Figure 7. Relative error histogram $|\mathrm{RE}|$ of $U_{m}$ mass humidity obtained using the gravimetric method, as well as $U_{m c}$ humidity identified by means of an artificial neural network for experimental verification (red curve shows the perfect fit for the normal distribution of the relative error).

\section{Conclusions}

Based on the research and analysis carried out to verify the neural method of assessing the humidity of saline brick walls, which was previously developed by the authors, the following conclusions can be drawn:

- It was shown that it is possible to reliably assess the humidity of a saline brick wall using an artificial neural network with a properly selected structure and learning algorithm on the basis of parameters assessed using the nondestructive dielectric and microwave methods.

- An artificial unidirectional multilayer neural network with backward error propagation and the algorithm for learning conjugate gradient (CG) is predisposed for this purpose. The obtained satisfactory value of the linear correlation coefficient $R$ of 0.807 confirms this statement.

- $\quad$ The correct identification of validation data was evidenced by the low average absolute error $|\Delta \mathrm{f}|$ value of $1.16 \%$ and the average relative error $|R E|$ of $19.02 \%$ (not very high for an in-situ study). Moreover, the relative error values $|R E|$ were mostly in the range of $15 \%$ to $25 \%$.

- The average $U_{m c}$ humidity value of $5.59 \%$ identified by the ANN was very close to the $U_{m}$ humidity value of $5.68 \%$ obtained by means of a test using the gravimetric method.

Further verification work is currently underway. This paper presents the results obtained to date, which are based on the results of testing two buildings. Ultimately, the group of buildings that will be used for verification purposes will be more numerous.

Author Contributions: Conceptualization, A.H. and Ł.S.; methodology, Ł.S.; software, Ł.S.; validation, A.H. and Ł.S.; resources, A.H.; data curation, A.H. and Ł.S.; writing-original draft preparation, Ł.S.; writing-review and editing, A.H.; visualization, A.H.; All authors have read and agreed to the published version of the manuscript.

Funding: This research received no external funding.

Conflicts of Interest: The authors declare no conflict of interest. 


\section{References}

1. Bajno, D.; Bednarz, L.; Matkowski, Z.; Raszczuk, K. Monitoring of thermal and moisture processes in various types of external historical walls. Materials 2020, 13, 505. [CrossRef] [PubMed]

2. Cabeza, A.P.; Camino, M.S.O.; Rodríguez, M.A.E.; Llorente, A.Á.; Pérez, M.P.S. Moisture influence on the thermal operation of the late 19th century brick facade, in a historic building in the city of Zamora. Energies 2020, 13, 1307. [CrossRef]

3. Guimarães, A.S.; Delgado, J.M.P.Q.; de Freitas, V.P.; Azevedo, A.C. Influence of different joints on moisture transport in building walls-A brief review. In Diffusion Foundations; Trans Tech Publications Ltd.: Bäch, Switzerland, 2019; Volume 22, pp. 19-23.

4. Falchi, L.; Slanzi, D.; Balliana, E.; Driussi, G.; Zendri, E. Rising damp in historical buildings: A venetian perspective. Build. Environ. 2018, 131, 117-127. [CrossRef]

5. Glavaš, H.; Hadzima-Nyarko, M.; Haničar, I.B.; Barić, T. Locating hidden elements in walls of cultural heritage buildings by using infrared thermography. Buildings 2019, 9, 32. [CrossRef]

6. Suchocki, C.; Damięcka, M.S.; Katzer, J.; Janicka, J.; Rapiński, J.; Stałowska, P. Remote detection of moisture and bio-deterioration of building walls by time-of-flight and phase-shift terrestrial laser scanners. Remote Sens. 2020, 12, 1708. [CrossRef]

7. Hoła, J. Degradacja budynków zabytkowych wskutek nadmiernego zawilgocenia-wybrane problemy. Bud. Archit. 2018, 17, 133-148. [CrossRef]

8. Goetzke, A.P.; Hoła, J. Influence of burnt clay brick salinity on moisture content evaluated by non-destructive electric methods. Arch. Civ. Mech. Eng. 2016, 16, 101-111. [CrossRef]

9. Czech Technical Standards. Waterproofing of Buildings-The Rehabilitation of Damp Masonry and Additional Protection of Buildings Against Ground Moisture and Against Atmospheric Water-The Basic Provision; CSN P 73 0610; Czech Technical Standards: Prague, Czech Republic, 2000.

10. WTA. WTA 2-6-99-D, Erganzungen Zum Merkblatt 2-2-91-D Sanierputzsysteme; WTA Publications: Zürich, Switzerland, 2001.

11. Hoła, A. Measuring of the moisture content in brick walls of historical buildings the overview of methods. In Proceedings of the 3rd International Conference on Innovative Materials, Structures and Technologies (IMST 2017), Riga, Latvia, 27-29 September 2017.

12. Rymarczyk, T.; Kłosowski, G.; Kozłowski, E. A non-destructive system based on electrical tomography and machine learning to analyze the moisture of buildings. Sensors 2018, 18, 2285. [CrossRef]

13. Concu, G.; Trulli, N.; Valdés, M. Knowledge acquisition of existing buildings by means of diagnostic surveying. Case studies. Int. J. Struct. Glass Adv. Mater. Res. 2018, 2, 22-29. [CrossRef]

14. Ruiz, L.V.; Flores, V.S.; Prieto, E.V. In situ assessment of superficial moisture condition in facades of historic building using non-destructive techniques. Case Stud. Constr. Mater. 2019, 10, e00228.

15. Freimanis, R.; Vaiskunaite, R.; Bezrucko, T.; Blumberga, A. In situ moisture assessment in external walls of historic building using non-destructive methods. Environ. Clim. Technol. 2019, 23, 122-134. [CrossRef]

16. Chastre, C.; Ludovico, M.M. Nondestructive testing methodology to assess the conservation of historic stone buildings and monuments. In Handbook of Materials Failure Analysis with Case Studies from the Construction Industries; Hamdy, A.S.M., Aliofkhazraei, M., Eds.; Elsevier: Alpharetta, GA, USA, 2018; pp. 255-294. ISBN 978-0-08-101928-3. [CrossRef]

17. Ince, I.; Bozdag, A.; Tosunlar, M.B.; Hatir, M.E.; Korkanc, M. Determination of deterioration of the main façade of the ferit pasa cistern by non-destructive techniques (Konya, Turkey). Environ. Earth Sci. 2018, 77, 420. [CrossRef]

18. Goetzke, A.P.; Hoła, A.; Sadowski, Ł. A non-destructive method of the evaluation of the moisture in saline brick walls using artificial neural networks. Arch. Civ. Mech. Eng. 2018, 18, 1729-1742. [CrossRef]

19. Goetzke, A.P. Identyfikacja Wilgotności Murów Ceglanych na Podstawie Badań Nieniszczących z Wykorzystaniem Sztucznych Sieci Neuronowych. Ph.D. Thesis, Wrocław University of Science and Technology, Wrocław, Poland, 2016.

20. Mishra, M.; Bhatia, A.S.; Maity, D. A comparative study of regression, neural network and neuro-fuzzy inference system for determining the compressive strength of brick-Mortar masonry by fusing nondestructive testing data. Eng. Comput. 2019, 1-15. [CrossRef] 
21. Mishra, M.; Bhatia, A.S.; Maity, D. Support vector machine for determining the compressive strength of brick-mortar masonry using NDT data fusion (case study: Kharagpur, India). SN Appl. Sci. 2019, 1, 564. [CrossRef]

22. Mishra, M.; Bhatia, A.S.; Maity, D. Predicting the compressive strength of unreinforced brick masonry using machine learning techniques validated on a case study of a museum through nondestructive testing. J. Civ. Struct. Health Monit. 2020, 10, 389-403. [CrossRef]

23. Nazarian, E.; Taylor, T.; Weifeng, T.; Ansari, F. Machine-learning-based approach for post event assessment of damage in a turn-of-the-century building structure. J. Civ. Struct. Health Monit. 2018, 8, 237-251. [CrossRef]

24. Wang, N.; Zhao, X.; Zhao, P.; Zhang, Y.; Zou, Z.; Ou, J. Automatic damage detection of historic masonry buildings based on mobile deep learning. Autom. Constr. 2019, 103, 53-66. [CrossRef]

25. Wang, N.; Zhao, Q.; Li, S.; Zhao, X.; Zhao, P. Damage classification for masonry historic structures using convolutional neural networks based on still images. Comput. Aided Civil Infrastruct. Eng. 2018, 33, 1073-1089. [CrossRef]

26. Tijskens, A.; Janssen, H.; Roels, S. Optimising convolutional neural networks to predict the hygrothermal performance of building components. Energies 2019, 12, 3966. [CrossRef]

27. Tijskens, A.; Roels, S.; Janssen, H. Neural networks for metamodelling the hygrothermal behaviour of building components. Build. Environ. 2019, 162, 106282. [CrossRef]

28. Chen, L.; Zhan, C.; Li, G.; Zhang, A. An artificial neural network identification method for thermal resistance of exterior walls of buildings based on numerical experiments. In Building Simulation, 3rd ed.; Tsinghua University Press: Beijing, China, 2019; Volume 12, pp. 425-440.

29. Hoła, A.; Sadowski, Ł. A method of the neural identification of the moisture content in brick walls of historic buildings on the basis of non-destructive tests. Autom. Constr. 2019, 106, 102850. [CrossRef]

30. Lourenço, P.B.; Luso, E.; Almeida, M.G. Defects and moisture problems in buildings from historical city centres: A case study in Portugal. Build. Environ. 2006, 41, 223-234. [CrossRef]

31. Brown, J.P.; Rose, W.B. Humidity and moisture in historic buildings: The origins of building and object conservation. APT Bull. J. Preserv. Technol. 1996, 27, 12-23. [CrossRef]

32. Sandrolini, F.; Franzoni, E. An operative protocol for reliable measurements of moisture in porous materials of ancient buildings. Build. Environ. 2006, 41, 1372-1380. [CrossRef]

33. D'Agostino, D. Moisture dynamics in an historical masonry structure: The Cathedral of Lecce (South Italy). Build. Environ. 2013, 63, 122-133. [CrossRef] 